\title{
On the Revaluation of Property, Plant and Equipment (PPE): Motivations, Value Relevance, and Effects on Audit Fees
}

\author{
Waresul Karim, AKM., ${ }^{1}$ Shariful Islam, Md. ${ }^{2}$ and Rafiqul Bhuyan ${ }^{3}$ \\ ${ }^{1}$ Alabama A \& M University, USA, ${ }^{2}$ Louisiana Tech University, USA, \\ ${ }^{3}$ Alabama A\&M University, USA
}

\begin{abstract}
This paper examines three important aspects of asset revaluations under International Financial Reporting Standards (IFRS). First, it seeks to identify characteristics of firms that choose to employ the revaluation model instead of the cost model while accounting for PP\&E. Hypothesizing both opportunistic and efficiency motives, the paper finds that firms with high leverage are more likely to choose the revaluation model, thus confirming contracting cost reasons, analogous to opportunistic motivation. However, the political cost reason of opportunistic motivation does not appear to be significant. On the other hand, our findings support that efficiency motive is highly significant behind asset revaluations, proving that firms with financial slack or those having higher percentage of investment in PPE are highly likely to choose the revaluation model, while those with growth opportunities are not. Second, given the managers' motivations for choosing the revaluation model, we find, using Ohlson (1995) model, that investors do not consider asset revaluation to be value relevant, proving that investors might already be aware of managers' motivation behind the choice. Finally, the paper empirically tests the effects of the use of the revaluation model on audit fees and finds that the choice of the revaluation model leads to a significant increase in audit fees. This finding supports the hypothesis that the use of the revaluation model involves additional audit effort that merits higher auditfees.
\end{abstract}

Keywords: motivations, value relevance, auditfees

\section{Introduction}

International Financial Reporting Standards (IFRS) have either been adopted or domestic standards have substantially been converged with it by many countries around the world including the UK, the European Union, Australia, Canada, China, India, Japan (partly), New Zealand, South Africa, and most developing countries and jurisdictions.
Countries like Bangladesh have adopted IFRS in their efforts to accelerate the pace of capital market development and do so with greater transparency and higher quality financial reporting. However, most of the research conducted on different aspects of IFRS revolve around developed countries particularly the EU countries. A negligible amount of research has focused on 
developing nations.

This research aims to focus on International Accounting Standard 16 (IAS 16) Property, Plant and Equipment (PPE) in the context of Bangladesh. An emerging economy with Gross Domestic Product (GDP) growing at an average $7.7 \%$ in the period of 2016-2019 (World Bank 2019), despite political instability, corruption, vulnerability to different natural and human calamities, the country has been consistently showing strong signs of growth that has surprised many of her development partners. On the accounting front, Bangladesh has been using IFRS/IAS since the beginning of the new century and since then has been trying to improve its institutional and regulatory framework for accounting, aiming to improve its capital market dominated by banks in meeting the financial needs of a fast expanding business sector. Unfortunately, very small amount of research has been conducted so far on different aspects of accounting standards such as IFRS/IAS.

The purpose of this paper is to investigate empirically such aspects of longterm asset revaluation as economic incentives, value relevance, and the effect of revaluation on very likely costs such as audit fees. Investigation of the choice of upward asset revaluation in the context of Bangladesh is interesting for a couple of reasons. First, most of the research undertaken so far on asset revaluation was concerned with firms in Anglo-Saxon environments, i.e., the EU, Australia, New Zealand, and the United Kingdom (Missonier-Piera 2007). As a result, we do not know much about the effect of such revaluation in developing economies although developing economies have enthusiastically been using it simultaneously or ahead of their AngloSaxon counterparts. Second, Bangladesh has a concentrated, and relatively illiquid, stock market that differs in many ways from those stockholder-oriented countries. This paper enhances our understanding of managers' accounting choices, particularly revaluation of assets, in such a shareholder regime where banks play a major role.

In order to investigate the rationale underlying upward asset revaluation choice of Bangladeshi firms, we derive hypotheses similar to those derived in other studies. Actually, we wish to see whether the hypotheses that apply elsewhere also do so in Bangladesh context and if so, to what extent and direction. Like other studies, we argue that asset revaluation embodies information cost hypothesis and fair value hypothesis (Shin and Willis 2014). The Information Cost Hypothesis, also called the Opportunism Hypothesis, holds that managers may choose to revalue their assets with reasons for reducing information costs in accessing the credit/capital markets and the Fair Value Hypothesis, also called the Efficient Hypothesis, holds that enhancing relevance of accounting information by replacing historical cost by fair values is likely to result in an increase in the value of the firm (Shin and Willis 2014). Given the reasons behind the choice of revaluation, it is corollary to ask what the capital market reaction could be to the revaluation information, that is, how the market reacts to information produced by the revaluation nodel. In other words, the value relevance of asset revaluation looks at asset revaluation from an information content perspective. In order to further investigate the value 
relevance of revaluation, we have used Ohlson (1995) model on a sample of Bangladeshi firms. Many studies in North America (Beaver and Landsman 1983; Beaver and Ryan 1985; Bernard and Ruland 1987; Bublitz, Frecka, and McKeown 1985; Hopwood and Schaefer 1989; Lobo and Song 1989) studied the value relevance of current cost accounting and reported mixed results regarding its relevance to firm value. Similar to North American studies, research on the value relevance of asset revaluation in Australia (Easton, Eddey, and Trevor 1993; Stnadish and Ung 1982), New Zealand (Emanuel 1989; Courtney \& Cahan 2004), the United Kingdom (Aboody, Barth, \& Kasznik 1999; Barth and Clinch 1998), South Korea (Shin and Willis 2014) and Hong Kong (Jaggi and Tsui 2001) provides mixed results. These studies attempted to identify abnormal returns on the firms' securities around the time the market became informed that a revaluation has taken place.

In addition to motivations and value relevance of revaluations, the paper looks at the costs of such decision. Though revaluation, by itself, has no discern direct cash flow effect but is costly to carry out (Brown et al. 1992), many companies choose to revalue PPE. It is therefore reasonable to think that these costs are compensated (Watts 1977) by some form of benefits accruing to the revaluing firms. The benefits of revaluation include - "true and fair" financial statement; confirming or correcting prior expectations about an entity's expected revenues; reduced debt contracting costs and increased borrowing capacity; and saving off potential unwanted takeover or attracting merger opportunities (Sardone and Tyson 2012). The direct and indirect costs of revaluation include decreases in reported income via increases in depreciation, valuer's fees, record keeping costs, higher audit fees, litigation costs, and additional management incentive and compensation costs (Sardone and Tyson 2012; Brown et al. 1992; Missonier-Piera 2007). It is evident that there are different types of costs involved with revaluation and many studies (Brown et al. 1992; Sardone and Tyson 2012; Missonier-Piera 2007) explicitly talked about audit fees associated with revaluation, but no studies have empirically tested the relationship between audit fees and revaluation. We contribute to the literature on asset reevaluation by empirically testing this hypothesis in a developing country context.

The rest of the paper is organized as follows: The next section describes the financial reporting context in Bangladesh and examines the issues associated with revaluation, the third develops the testable hypotheses in the context of this study, the fourth presents the research design, the fifth discusses the main empirical findings while the sixth draws a conclusion.

\section{Accounting for Asset Revaluation in Bangladesh}

Asset revaluations are defined as the restatement of an asset's book value to some current market, or fair, value (Brown et al. 1992). According to IAS 16 of IFRS, although at initial recognition, all assets must be recognized at cost, two choices are available at subsequent reporting periods: the cost model and the revaluation model. Under the cost model, items of PPE are recorded at cost and are carried at cost subject to depreciation and possible 
impairments. According to IAS 16, paragraph 30 , the entity shall carry the items of PPE at their historical cost less applicable accumulated depreciation and accumulated impairment losses. On the other hand, the revaluation model allows entities to revalue assets on a 'systematic' basis. Revaluation is allowed to ensure carrying amounts are not materially different from their fair values. The main strength of the revaluation model is its ability to produce information that is more relevant than that produced by the historical cost (HC) model. Fair value is claimed to be conceptually superior to historical costs. However, historical cost is claimed to be more reliable as it is easy to verify and hence possesses a greater degree of representational faithfulness. Under the revaluation model, the carrying amount would be equal to the revalued amount as of the revaluation date. The revalued amount is equal to the fair value at the date of revaluation, minus any subsequent accumulated depreciation and subsequent impairment losses (IAS 16.31). Under IFRS, revaluations should be made with "sufficient regularity," but do not need to be conducted annually. The length of time between revaluations depends upon the change in fair value, with "material" variance between the asset's fair value and carrying amount necessitating more frequent revaluations (IAS 16.34). In addition, revaluation is supposed to be carried out on a class-by-class basis. That means if an item of PPE is revalued, then the entire class the asset belongs to must be revalued (IAS 16.36).

With respect to measurement, if the revaluation causes the carrying amount to increase, the increase is recognized in other comprehensive income and accumulated in shareholders' equity under an account titled "Revaluation Surplus"; however, the increase should be recognized in profit and loss, to the extent that it reverses a previous revaluation decrease for the same asset previously recognized (IAS 16.39). If, on the other hand, revaluation leads to a decrease in the carrying amount, the decrease is recognized against any revaluation surplus belonging to that asset, to the extent of any credit balance existing in the revaluation surplus account with respect to that asset. If the revaluation surplus is reduced to zero, any remaining decreases are recognized in profit and loss; if there is no revaluation surplus, the decrease is recognized in profit or loss (IAS 16.40). When the asset is derecognized, any balance of the revaluation surplus may be transferred to retained earnings (IAS 16.41).

Presenting PPE at fair value directly supports one of the fundamental qualitative characteristics of accounting information: relevance. It also enables users to confirm or correct prior expectations about an entity's expected revenues and returns on assets. Because the primary users of financial reporting information are the capital providers (investors and creditors), revaluing PPE to fair value should better enable these parties to use this information for predicting future cash flows that derive from the use, sale, or exchange of revalued assets-as opposed to the information associated with assets carried at historical costs.

Upward revaluation contrasts with the cost method, which clearly prioritizes faithful representation (i.e., reliability) over relevance. Reliable information is potentially less biased and can be more 
easily verified through primary documents; however, carrying long-lived nonfinancial assets at cost provides neither the predictive nor the confirmatory value that external users need to make decisions regarding those assets. Upward revaluations can also benefit entities by enabling reduced debt contracting costs and potentially providing increased borrowing capacity, although this might only affect the related accounting exercise as the market and individual investors have generally adjusted for current values of assets. Upward revaluations could also lead to lower leverage and higher collateral values, both of which are beneficial when trying to secure loans. Other benefits include the ability to clearly display the fair market value of assets that appreciate over time-such as land and buildings - and directly impact key ratios that include fixed assets. This is especially important when dealing with banks or other creditors that want to see the true value of a company when determining the potential size and terms of a loan. Moreover, upward revaluation could stave off potential unwanted takeovers or attract merger opportunities by increasing the entity's market capitalization.

\section{Background and Explanatory Factors}

Asset revaluations have been a topic of controversy in both the accounting and finance literature for decades (Dillon 1979). Asset revaluation is an option under IAS 16. Therefore, some managers adopt it and some do not and the adoption of a policy of asset revaluation involves costs. So different studies delve into the incentives managers may have to do it. Most of the studies on revaluation were done in the 1980s and the 1990s. These studies try to explain the reasons of revaluation and over time, and as part of their work, two competing theories have been developed and gained empirical support.

Opportunism theory, also called Information Cost Hypothesis, argue that a revaluation affects contracting and political costs. Therefore, managers are not indifferent to how and when they revalue their firms' assets (Brown et al. 1992). Upward asset revaluations increase the carrying amount of the assets and lower the debt ratio, resulting in an increase in the proportion to the value of assets in place and thus making access to external funds easier and cheaper for high information cost firms (Shin and Willis 2014). Therefore, these firms may have opportunistic motivations to revalue assets upwards because of the greater probability of viable projects being passed up (Courtney \& Cahan 2004). In a bank-centered economy such as Bangladesh the borrowing capacity of the firm depends on the value of the collateral it can offer. Since asset revaluation increases the value of the collateral, it helps revamping a firm's debt capacity. Research has confirmed that firms that report fixed assets using fair market values are able to receive significantly higher loans from banks (Nicholos and Buerger 2002). This Opportunism Theory has got academic support (Brown et al. 1992; Whittred and Chan 1992; Black et al. 1998), but there is also evidence that does not support the theory (Jaggi and Tsui 2001).

On the other hand, Efficient Theory, also called Fair Value Hypothesis, argue that asset revaluation may result in 
more relevant information, thus ensuring higher qualitative characteristics of accounting information. The decision to revalue assets also has signaling content (Shin and Willis 2014). Under information asymmetry, managers of firms that believe their firms are undervalued may signal their true value of assets through asset revaluation. In reality, a good firm may not risk lowering future earnings ratios to improve the debt ratios by revaluing its assets. Gaeremynck and Veugelers (1999) support the signaling content of asset revaluations. Therefore, asset revaluations undertaken by quality firms may signal their good intention for fair value reporting and result in positive reaction from the market.

In addition, revaluations also serve to dissuade hostile takeover bids (Missonier-Piera 2007). If revaluation allows a firm to bring its book value in line with its fair value, this move lowers the probability of a successful under-value bid (Brown et al. 1992; Easton, Eddey, and Trevor 1993). Furthermore, by reducing Return on Equity (ROE) and Return on Assets (ROA), upward revaluation reduces political costs borne by firms (Brown et al. 1992). Finally, when gain from a sale of fixed assets could be calculated based on historical cost and flow through the income statement, revaluation could be part of an overall earnings management policy (Black et al. 1998).

\section{1 (a) Opportunism Hypothesis} (Contracting reasons)

Bangladesh credit market is not well-developed, with banking industry dominating the financial system. Market capitalization of stock exchanges is 29.93 billion USD (www.tradinghours.com on 11
June, 2020), with market capitalization to G D P ratio $13.5 \%$ in 2019 (www.ceicdata.com). In addition, the capital market is still delicately volatile; so the banking industry is dominating the credit market. Creditors use accounting information to analyze a firm's financial standing and assess the risk they would be taking when granting credit or approving a loan. Managers seeking to reduce financing costs may influence the accounting decisions to reduce the perceived risk of bankruptcy, and thus reduce debt costs. Managers will try to reassure creditors by opting for an upward revaluation policy for fixed assets, thus reducing information asymmetry about the assets' fair value and reducing leverage ratios as well as the perceived bankruptcy risk.

H1a: The higher the firm's leverage, the more incentives its managers have to use upward asset revaluation.

(b) Opportunism Hypothesis (Political reasons)

Accounting numbers may be used to justify corporate actions in a politically regulated environment (Brown et al. 1992). When a bigger firm reports high profits, it is very likely that regulators and other constituents who may have incentives and capacity to reallocate resources away from the firm may create pressure on it. Under such circumstances, larger firms are more likely to adopt income-reducing procedures and to cut the expected loss from regulation. Given that managers' incentives are aligned more closely with those of shareholders, managers might undertake an upward revaluation to lower the firm's ROE because, ceteris paribus, a lower return can reduce political costs and increase the value of the firm (Brown et al. 1992). 
H1b: Larger firms are more likely to revalue fixed assets than are smaller firms.

\section{(c) Efficient Hypothesis (Information} Asymmetry reasons-Financial Slack)

Information asymmetry arises when one party to a potential transaction has information not held by another (Brown et al. 1992). With information asymmetry, it is generally assumed that outsiders cannot observe corporate attributes in detail to calculate security values; therefore, managers of firms with undervalued shares have an incentive to expend additional resources, such as by paying a higher dividend or incurring additional costs of revaluation. Given this information asymmetry, a firm with sufficient financial slack can avoid higher external financing costs and can take on profitable new projects which otherwise might be passed over (Myers and Majluf 1984). Financial slack can take the form of liquid assets such as current assets, and reserve borrowing capacity. The size of the financial slack depends on the difference between book value and market value. In case of PPE this difference depends on the firm's current investment in PPE among many other things (Brown et al. 1992). Revaluations can be carried out with economies of scale. Ceteris paribus, the higher the amount of PPE, the greater the likelihood of revaluation of fixed assets (Brown et al. 1992).

H1c: The higher a firm's relative dollar investment in PPE, the greater the probability of revaluation of fixed assets.

As mentioned earlier, financial slack can take the form of liquid assets such as current assets, and reserve borrowing capacity. Ceteris paribus, the smaller the existing financial slack, the greater the gain to the firm from revaluing fixed assets; however, during periods of higher inflation, if the slack consists of current assets, the firm could have an incentive to revalue in order to hold slack in the form of reserve borrowing capacity because the opportunity cost of holding slack in the form of cash and marketable securities increases with inflation. Following Brown et al. (1992) our hypotheses are:

H1c(i): Firms are more likely to revalue assets when they have lower holdings of current assets relative to total assets, than when they have higher holdings current assets relative to total assets.

H1c(ii): Given high inflation, firms with higher holdings of current assets relative to total assets are more likely to revalue than firms with lower holdings of current assets relative to total assets.

(d) Efficient Hypothesis (Information Asymmetry reasons-Growth)

Brown et al. (1992) argue that firms with more growth options will value financial slack more highly because of the greater probability of viable projects being passed up because of higher external financing costs. As a result, they would be more likely to revalue in order to have sufficient slack to avoid potential underinvestment. However, MissonierPiera (2007) argue that growth may have two countervailing associations with asset revaluation policy. First, firms composed mainly of investment (growth) opportunities have fewer assets-in-place. From this perspective, these growth firms have fewer possibilities than firms composed mainly of assets-in-place to revalue their assets upward. In fact, fixed 
asset revaluation may concern only existing assets. Second, managers of firms composed mainly of growth opportunities are better acquainted with their value than are outside investors. Therefore, it is more difficult to control the activities of growth firms than it is to control the activities of firms composed mainly of assets-in-place. Creditors then perceive such growth firms as more risky, giving an incentive to opt for upward revaluations of fixed assets (Whittred and Chan 1992). Because of these two opposite arguments, it is difficult to make a priori about the sign of the association between growth opportunities and upward revaluation of fixed assets.

H1d: Firms' growth opportunities are associated with the use of the revaluation model to value PPE.

\subsection{Value relevance of asset revaluation}

Given the reasons of the choice of revaluation, it is corollary to ask what the capital market reaction is to the revaluation information, that is, how the market reacts to revaluation. In other words, value relevance of asset revaluations looks at asset revaluation from an information content perspective. To test the value relevance of asset revaluation, studies (Beaver and Landsman 1983; Beaver and Ryan 1985; Bernard and Ruland 1987; Bublitz, Frecka, and McKeown 1985; Hopwood and Schaefer 1989; Lobo and Song 1989; Easton, Eddey, and Trevor 1993; Stnadish and Ung 1982; Emanuel 1989; Courtney \& Cahan 2004; Aboody, Barth, \& Kasznik 1999; Barth and Clinch 1998) attempted to identify abnormal returns on the firms' securities around the time the market became informed that a revaluation has taken place.

Value relevance is defined as the ability of accounting information to capture or summarize information affecting companies' share values, regardless of source. It could be identified as the explanatory power of accounting variables, such as earnings and book value of equity, cash flows or other relevant variables, selected by other authors, in explaining stock price. Market value relevance indicates a statistical association between financial information and market prices or stock returns. Consequently, under the efficient markets hypothesis that shareprices reflect all publicly available information, the accounting-based measures could explain market price in an effective way (Francis and Schipper, 1999). This study uses Ohlson's (1995) residual income valuation model, in which firm value is explained by a combination of its book value and abnormal earnings - market value is a function of book value and present value of residual earnings.

Generally, value relevance studies use either a price model or a return model (Barth , Beaver, \& Landsman, 2001; Ota, 2003). Both models are derived from the Ohlson (1995) model. In the past, some studies (Sami \& Zhou, 2004; Bao \& Chow, 1999) have used both the return and price models, generating similar results. However, other studies have generated opposing results when using both models (Ely \& Waymire, 1999; Francis \& Schipper, 1999). In this paper we have decided to base our analysis using the price model. We chose this over the return model simply because the cumulative effect of independent variables reflect share price (Chen, Chen, \& 
Su, 2001; Kothari \& Zimmerman, 1995). This, therefore, makes the estimated slope coefficient of the test variable unbiased. As a result of this, the variables will be value relevant if they are related to the share price without any new information being disclosed. For this specific reason, the price model will be used in this study.

H2: The revaluation model is value relevant.

\subsection{Costs of asset revaluation}

Though revaluation, by itself, has no discern direct effect on cash flows and is costly to carry out (Brown et al. 1992), many companies revalue fixed assets. The direct and indirect costs of revaluation include valuer's fees, record keeping costs, higher audit fees, litigation costs, and additional management incentive and compensation costs (Sardone and Tyson 2012; Brown et al. 1992; Missonier-Piera 2007). It is evident that there are different types of costs involved with revaluation and many studies (Brown et al. 1992; Sardone and Tyson 2012; Missonier-Piera 2007) explicitly talk about audit fees associated with revaluation, but no studies empirically tested the relationship between audit fees and revaluation.

Since Simunic (1980), audit fee literature continued to grow in different dimensions. Hay et al. (2006), in a metaanalysis of audit fee literature, examine the determinants of audit fees, finding that the determinants may be classified as client attributes, auditor attributes, and characteristics specific to audit engagement. Most of the research focuses on client attributes, suggesting that audit fees increase with increases in client size (Simunic 1980), risk (Stice 1991), and complexity (Hackenbrack and Knechel 1997). Many studies also focus on individual countries to report on the effects of IFRS adoption on audit fees. (Griffin et al. 2009, New Zealand; Vieru and Schadewitz 2010, Finland; Kim et al. 2012, EU; Degorge et al. 2013, Australia). Recent studies examining the relation between fair value and audit fees confirm that auditors charge higher audit fess as the proportion of fair value assets increases (Michael Ettredge et al. 2014). A note-worthy characteristic of the studies dealing with the effects of IFRS adoption on audit fees is that all of them focus on the same thing - whether IFRS adoption leads to higher audit fees in their respective jurisdictions. Their findings confirm that IFRS adoption does lead to an increase in audit fees. However, a large gap exists in this research because very few studies investigate the different aspects of IFRS contributing to the increase in audit fees. We will explore here how audit fees go up as a result of revaluation of fixed assets.

H3: There is no significant association between the choice of the revaluation model rather than the cost model to value PPE and the level of audit fees paid while controlling for corporate and auditor attributes.

\section{Research Design}

\subsection{Sample Selection}

The sample comprises firms listed on Dhaka Stock Exchange (DSE) for the periods of 2013 and 2014. We did not include banks and non-bank financial institutions because they possess different characteristics from other listed firms. Data were collected from S\&P Capital IQ database situated at Lumpkin School of Business at Eastern Illinois University. We got most of our variables from S\&P Capital IQ database except audit fees, audit firm, the 
choice of the revaluation or the cost model. To obtain the missing variables, we used annual reports published by the sample companies. We manually input those variables into our data matrix. For H3, we used data for only 2014 as because of time constrains we could not enter more data points. Table 1 presents the number of companies included from each industry covered in the study.

\subsection{Variable Measurement}

For the study we measure variables in line with other studies. Table 2 represents the names of variables, their descriptions and the sources from which they are collected. The choice of the revaluation model or the cost model is represented by revcost, which is a dummy variable where 1 represents the companies which revalue and 0 represents companies that use cost model. For hypothesis $\mathrm{H} 1$, revcost is the dependent variable, while for $\mathrm{H} 2$ and $\mathrm{H} 3$ it is an independent variable. To measure risk, we use debt-to-equity ratio (deequi) as our leverage variable. This leverage measurement is in line with some studies in audit fee literature (Karim and Moizer 1996) but different from economics of revaluation literature (Brown et al. 1992; MissonierPiera 2007), in which leverage is measured as a ratio of total debt-to-total assets. For H1, to measure financial slack we use ppeta, which is the ratio of PPE to total assets. The nature of the firms' assets should provide a more accurate value of the size of the slack. In addition, we have also used the amount of current assets as financial slack and hypothesized in H1c (i) and H1c (ii) that they are related to revaluation. This aspect is measured by cata, which is the ratio of current assets-to-total assets. In line with political reasons of the Opportunism
Hypothesis, we have measured the size of the company by logsales, which is the natural logarithm of sales of the sample companies. This is in line with MissonierPiera (2007) study. However, many studies measure the size of the companies by the natural logarithm of total assets (Brown et al. 1992). The logsales is also an explanatory variable in $\mathrm{H} 3$. The growth potential of a company is measured by market-to-book ratio $(m v b v)$. To measure growth other studies use either price-earnings $(\mathrm{P} / \mathrm{E})$ ratio (Brown et al. 1992) or market-to-book value ratio (Shin and Willis 2014). The variable audfirm is a dummy variable, indicating whether the company is audited by a Big 4 audit firm or not. It indicates audit quality. We assume if firms are audited by Big 4, then they charge extra audit fees because of high audit qualities associated with their brand names. In case of audit quality, studies have reported mixed findings; Simunic (1980) found no evidence of significantly higher audit fees charged by the Big 8 firms in the US except Price Waterhouse (now PWC), regardless of auditee size. Other studies, however, have found a relation between audit firm size and audit fees (Taffler and Ramalinggam 1982; Francis 1984; Palmrose 1986; Francis and Stokes 1986; Francis and Simon 1987). The variable nise is the net income divided by stockholders' equity, representing Return on Equity (ROE), which measures the profitability of companies. The effect of profitability is hard to measure because of two opposite effects: (i) Greater profitability could mean that the company is less concerned with individual overhead and hence audit fee could be lower (Karim and Moizer 1996). Alternatively, low profitability could be associated with financial pressure, which would require increased audit work to verify the value of 
assets and to confirm that the company is a going concern. Hence low profitability could be associated with higher audit fees. This view reflects the extent of audit risk jointly with leverage. The higher the audit risk, the higher the audit fees (Stice 1991). The higher the ROE, the less risks involved in audit effort and vice-versa. Therefore, there is an uncertain relationship between ROE and audit fees. As indicated by the prior research on audit fees, the size of the auditee is one of the most important independent variables to explain audit fees. Audit effort is expected to increase, as the size of the auditee increases (Goncharov 2014). In larger companies, additional detailed audit procedure and tests have to be implemented, thus involving more time, more effort, more data, and more information (Simunic, 1980). The variable lgta is the natural logarithm of total assets, representing the size of a company. Therefore, there is a positive relationship between audit fee and client size. The variable $m v \_v r$ is the market value of a company; actually it represents the market capitalization of companies. In $\mathrm{H} 2$, it is our dependent variable. The variable $b v_{-} v r$ is the book value of companies; it is the stockholders' equity. The residual earnings in value relevance model is represented by the variable pvre, which is the present value of residual earnings. Residual earnings represent the abnormal earnings over expected income. The Ohlson (1995) model is based on residual earnings whereby the value of the firm is estimated as its book value plus the present value of its lifetime residual, or abnormal, earnings. In $\mathrm{H} 3$, the dependent variable is represented by the variable lgaudfee, which is the natutal logarithm of audit fees paid by the sample firms. Finally, the variable invrecvta represents the sum of inventory and receivables divided by total assets. This variable measures audit complexity. As audit complexity increases, so does audit fees. The companies with higher proportion of inventory and accounts receivable against total assets are likely to have to pay higher auditfees.

\section{Empirical Results}

For H1, the dependent variable is the choice of either the revaluation model or the cost model, so it is a dichotomous variable. For this reason, we have used Logit model of regression. The pairwise correlation of independent variables of $\mathrm{H} 1$ is presented in Table 3. It is evident from the correlation matrix that there is no high correlation between explanatory variables except between $m v b v$ and deequi and between cata and ppeta. The result of hypothesis testing is presented in Table 5 in Model 1. From Model 1, it is evident that firms with higher leverage are likely to choose the revaluation model. This finding is consistent with previous findings in the literature on studies conducted in Australia, the United Kingdom, and New Zealand (Black et al. 1998; Brown et al. 1992; Whittred and Chan 1992; Cotter 1999; Cotter \& Zimmer 1995). Inconsistent with Brown et al. (1992), corporate size is not found to be significant in explaining the choice because we have seen from previous studies that Bangladeshi firms have a tendency to show more profits rather than reduce profits opportunistically. However, relative investment in PPE (ppeta), ratio of current assets to total assets (cata), and growth ratio $(m v b v)$ appear to be significant in explaining the choice of the model, though the growth firms are not likely to choose the revaluation model. These 
findings are consistent with existing literature. The Logit model is significant at the 0.05 level. However, its explanatory power is modest in that Pseudo $\mathrm{R}^{2}$ is about $13.17 \%$, a finding that is consistent with Brown et al. (1992). To sum up, it is reasonable to conclude that financial slack, signaling reasons, contracting costs are statistically significant in explaining the choice of the measurement model. Political costs are not significant, supporting the fact that managers in Bangladesh do not have a tendency to hide or smooth earnings. These findings are supported by the experience as we have seen there are a very few regulatory or other forces causing managers to contemplate to smooth or reduce profits.

On value relevance of the revaluation model, we find that model is not value relevant; market does not consider it highly relevant, or make revaluation information extra useful to make their decisions. Actually, this finding is consistent with findings from Model 1, which confirms both Opportunistic and Efficient Hypotheses. From this findings, we conclude that market has a good amount of information about the motives of managers following the revaluation model. We further conclude that market mostly views it as an opportunistic behavior on the part of managers. In Model 2 , book value $(b v)$ and present value of residual earnings (pvre) are higly significant, a finding consistent with Ohlson (1995) model.

Finally, in our cost model of revaluation choice (Model 3), as expected, we find the decision to revalue to be costly as it increases audit fees. Previous studies (Brown et al. 1992; Sardone and Tyson 2012; Missonier-Piera 2007) also hypothesized that revaluation increases the cost of audit fees, but no studies tested it empirically. In Model 3, for control variables, we do not find leverage (deequi) and profitability ratios (nise) to be significant; these findings are inconsistent with those of previous studies.

\section{Conclusion}

The study investigates such aspects of revaluation model as the motivation of managers to choose the revaluation model, the value relevance of the model to investors, and the cost of choosing the model. The firms with high leverage are likely to choose revaluation model, confirming the Opportunism Hypothesis. However, big firms are not likely to choose revaluation model as we expected that big firms might take income-reducing accounting choice for political reasons. On the other side, firms with higher financial slack, or higher percentage of investment in PPE, or those with growth opportunities are likely to choose the revaluation model, confirming that many firms choose the revaluation model efficiently. When we turn our attention to the market for its reaction, we see the market does not find this choice value relevant, explaining the fact that market might be already aware of the opportunistic behavior on the part of the managers. Finally, the choice of revaluation is costly because it increases the cost of audit.

In spite of the statistical significance of the model, we recognize that there might be problems in the specification of variables. In addition, the sample size might not be high enough to lend absolute credibility to our findings. However, after all, the study explains the 
managers' behavior in a developing country, which appear to be very much different from those of developed countries.

\section{References}

Aboody D, Barth M E, and Kasznik R (1999) "Revaluations of fixed assets and future firm performance: evidence from the UK" Journal of Accounting and

Economics 26, 149-178.

Bao B \& Chow L (1999) “The Usefulness of Earnings and Book Value for Equity Valuation in Emerging Capital Markets: Ecidence from Listed Compaines in the People's Republic of China" Journal of Inernational Financial Management \& Accounting 10(2), 85-104.

Barth M E and Clinch G (1998) "Revalued financial, tangible, and intangible assets: association with share prices and nonmarket based value estimates" Journal of Accounting Research 36, 199-247.

Barth M, Beaver W, and Landsman W. (2001). "The Relevance of the Value Relevance Literature for Financial Accounting Standard Setting: Another View" Journal of Accounting and Economics 31 (1-3), 77-104.

Beaver W H and Landsman W R (1983) "Incremental information content of Statement 33 disclosures" FASB,

Stamford, Connecticut.

Beaver W H and Ryan S G (1985) "How well do Statement No 33 earnings explain stock returns? Financial Analysts Journal 41, 66-71.

Bernard V L and Ruland R (1987) "The Incremental Information Content of historical cost and current cost income numbers: time series analyses for 1962180" The Accounting Review 62, 707-722. Black E L, Sellers K F, and Manly T S
(1998) "Earnings management using asset sales: an international study of countries allowing noncurrent asset revaluation" Journal of Business Finance and Accounting 25(9-10), 1287-1317.

Brown P, Izan H Y, and Loh A L (1992), "Fixed asset revaluations and managerial incentives" Abacus 28(1), 36-57.

Bublitz B, Frecka T J, and McKeown J C (1985) "Market associations tests and FASB Statement No 33 disclosures: a reexamination/discussion" Journal of Accounting Research 23, 1-27.

Chen C, Chen S, \& Su X (2001) "Is Accounting Information Value-Relevant in the Emerging Chinese Stock Market?" Journal of Accounting, Auditing, and Taxation 10(1), 1-22.

Cotter J (1999) “Asset revaluation and debt contracting" Abacus 35(3), 268-285. Cotter J and Zimmer I (1995) “Asset revaluation and assessment of borrowing capacity" Abacus 31(1), 136-151. Courtney S and Cahan S (2004) "The impact of debt on market reaction to revaluation of noncurrent assets" PacificBasin Finance Journal 12, 219-243.

De George E. M., Ferguson, C.B. \& Spear N.A (2013) "How Much Does IFRS Cost? IFRS Adoption and Audit Fees" The Accounting Review 88(2), 429 - 462.

Dillion G J (1979) “Corporate asset revaluations: 1925-1934” The Accounting Horizons Journal 6(1), 1-15.

Easton P D, Eddey P H, and Trevor H S (1993) "An investigation of revaluation of tangible long-lived assets. Journal of Accounting Research 31, 1-38. Ely K \& Waymire G (1999) “Accounting Standard-setting Organizations and Earnings Relevance: Longitudnal Evidence from NYSE Common Stocks" Journal of Accounting Research 37(2), 293-317. 
Emanuel D M (1989) “Asset revaluation and share price revision" Journal of

Business Finance and Accounting 16, 213 228.

Ettredge M L, Xu Y, and Yi H S (2014)

"Fair Value Measurement and Audit Fees:

Evidence from Banking Industry"

Auditing: A Journal of Practice \& Theory 33(3), 33-58.

Francis J. R. and D. J. Stokes (1986) "Audit Prices, Product Differentiation, and Scale Economies: Further Evidence from the Australian Market" Journal of Accounting Research 24(2) Autumn, 383393.

Francis J. R. and D. J. Stokes (1986) "Audit Prices, Product Differentiation, and Scale Economies: Further Evidence from the Australian Market" Journal of Accounting Research 24(2) Autumn, 383393.

Francis J. R. and Daniel T. Simon (1987) "A Test of Audit Pricing in the Small Client Segment of the U. S. Audit Market" The Accounting Review, 62 (1) January, 145-157

Francis J and Schipper K (1999) "Have financial statements lost their relevance?" Journal of Accounting Research 37(2), 319-352.

Gaeremynck A and Veugelers R (1999)

"The revaluation of assets as a signaling device: A theoretical and empirical analysis" Accounting and Business Research 29(2), 123-138.

Goncharov, I., Riedl, E. J., \& Sellhorn T. (2014) "Fair Value and Audit Fees" Review of Accounting Studies, 19:210-241.

Griffin P. A. Lont D. H. \& Sun Y. (2009) "Governance regulatory changes, International Financial Reporting Standards adoption, and New Zealand audit and nonaudit fees: empirical evidence" Accounting and Finance 49(4), 697-724.

Hackenbrack K. \& Knechel W. R (1997) "Resource allocation decisions in audit engagements" Contemporary Accounting Research 14, 481-500

Hay D. C., W. R. Knechel, and N. Wong (2006) "Audit fees: A meta-analysis of the effect of supply and demand attributes" Contemporary Accounting Research 23,141-191.

Hopwood W and Schaefer T (1989) "Firmspecific responsiveness to input price changes and the incremental information content in current cost income" The Accounting Review 64, 312-338. Jaggi B and Tsui J (2001) "Management Motivation and Market Assessment: revaluation of fixed assets" Journal of International Financial Management and Accounting 12(2), 160-187.

Karim AKMW and Moizer P (1996)

"Determinants of audit fees in

Bangladesh" The International Journal of Accounting 31(4), 497-509.

Kim J. B., Liu X. \& Zheng,L. (2012) “The impact of mandatory adoption on audit fees: Theory and evidence" The Accounting Review 87(6), 2061-94.

Kothari S, \& Zimmerman J (1995) "Price and Return Models" Journal of Accounting and Economics 20(2), 155-192.

Lobo G J and Song I M (1989) "The incremental information in SFAS No. 33 income disclosures over historical cost income and its cash and accrual components" The Accounting Review 64, 329-343.

Missionier - Piera F (2007) "Motives for fixed-asset revaluation: An empirical analysis with Swiss data" The

International Journal of Accounting 42, 186-205

Myers S and Majluf N (1984) "Corporate 
financing and investment decisions when firms have information that investors do not have" Journal of Financial Economics. Nicholas L M and Buerger K H (2002) "An investigation of the effect of valuation alternatives for fixed assets on the decisions of statement users in the United States and Germany" Journal of International Accounting, Auditing and Taxation 11(2), 155-163.

Ohlson J (1995) "Earnings, book values and dividends in security valuation" Contemporary Accounting Research 11, 661-687

Ota K. (2003) "The Impact of Price and Return Models on Value Relevance Studies: A Review of Theory and Evidence" Accounting Research Journal 16 (1), 6-20.

Palmrose Z.V. (1986) "Audit Fees and Auditor Size: Further Evidence" Journal of Accounting Research 24 (1) Spring, 97-110 Sami H \& Zhou H (2004) “A Comparison of Value Relevance of Accounting Information In Different Segments of the Chinese Stock Market" The International Journal of Accounting 29(4), 403-427. Sardone D and Tyson T (2012) "Upward revaluation of nonfinancial assets" The CPA Journal, 26-30

Shin G H and Willis V F (2014) “Asset Revaluation under International Accounting Standard 16: Evidence from
Korea" International Journal of Business, Accounting, and Finance 8(2), 21-36

Simunic D. A. (1980) "The pricing of audit services: Theory and evidence" Journal of Accounting Research 18 (1), 161-190.

Standish P E \& Ung S I (1982) "Corporate signaling, asset revaluation and stock prices of British Companies" The Accounting Review 57, 701-716.

Stice J. D. (1991) "Using financial and market information to identify preengagement factors associated with lawsuits against auditors" The Accounting Review 66, 516-533.

Taffler R. J. and K. S. Ramalinggam (1982) "The Determinants of Audit Fees in the UK: An Exploratory Study" City University Business School Working Paper No. 37, London

Vieru M. \& Schadewitz H. (2010) “Impact of IFRS transition on audit and non-audit fees: Evidence from small and mediumsized listed companies in Finland" The Finnish Journal of Business Economics 14(1), 11-41.

Watts R L (1977) “Corporate financial statements, a product of the market and political processes" Australian Journal of Management 2, 53-75.

Whittred G and Chan Y K (1992) “Asset revaluations and the mitigation of understatement" Abacus 28(1), 58-74. 


\section{Appendices}

\section{Table 1 (Number of Companies Sampled)}

\begin{tabular}{|c|c|c|c|}
\hline & Quantity & Covered & Percentage \\
\hline Cement & 7 & 4 & $57.14 \%$ \\
\hline Ceramics & 5 & 2 & $40.00 \%$ \\
\hline Engineering & 32 & 12 & $37.50 \%$ \\
\hline Food \& Allied & 18 & 8 & $44.44 \%$ \\
\hline Fuel \& Power & 18 & 10 & $55.56 \%$ \\
\hline IT Sector & 7 & 3 & $42.86 \%$ \\
\hline Jute & 3 & 1 & $33.33 \%$ \\
\hline Miscellaneous & 12 & 4 & $33.33 \%$ \\
\hline Paper \& Printing & 2 & 0 & $0.00 \%$ \\
\hline Pharmaceuticals \& Chemicals & 27 & 9 & $33.33 \%$ \\
\hline Services \& Real Estate & 4 & 3 & $75.00 \%$ \\
\hline Tannery Industries & 5 & 3 & $60.00 \%$ \\
\hline Telecommunications & 2 & 1 & $50.00 \%$ \\
\hline Textile & 43 & 5 & $11.63 \%$ \\
\hline Travel \& Leisure & 4 & 0 & $0.00 \%$ \\
\hline TOTAL & 189 & 65 & $34.39 \%$ \\
\hline
\end{tabular}

Table 2 (Measurement of Variables)

\begin{tabular}{|c|c|c|c|}
\hline Variable & Measure & Description of variable & Data source \\
\hline revcost & $\begin{array}{l}\text { Revaluation model or cost } \\
\text { model }\end{array}$ & $1=$ revaluation model $; 0=$ cost model & Annual Report \\
\hline deequi & Total Debt/Total Equity & The ratio of debt to equity & $\begin{array}{l}\text { S\&P Capital } \\
\text { IQ }\end{array}$ \\
\hline ppeta & $\begin{array}{l}\text { Property, Plant and } \\
\text { Equipment(PPE)/Total Assets }\end{array}$ & $\begin{array}{l}\text { Percentage of total assets invested in } \\
\text { PPE }\end{array}$ & $\begin{array}{l}\text { S\&P Capital } \\
\text { IQ }\end{array}$ \\
\hline cata & Current Assets/Total Assets & $\begin{array}{l}\text { Percentage of total assets invested in } \\
\text { current assets }\end{array}$ & $\begin{array}{l}\text { S\&P Capital } \\
\text { IQ }\end{array}$ \\
\hline logsales & Log of total sales & Measures the size of the company & $\begin{array}{l}\text { S\&P Capital } \\
\text { IQ }\end{array}$ \\
\hline$m v b v$ & Market value/ Book Value & $\begin{array}{l}\text { Market to book ratio represents } \\
\text { growth opportunity }\end{array}$ & $\begin{array}{l}\text { S\&P Capital } \\
\text { IQ }\end{array}$ \\
\hline audfirm & Big -4 or Non Big-4 audit firm & $\begin{array}{l}1=\text { Big- } 4 \text { audit firm; } 0=\text { Non Bigh- } 4 \\
\text { audit firm }\end{array}$ & Annual Report \\
\hline nise & $\begin{array}{l}\text { Net Income/Stockholders } \\
\text { Equity }\end{array}$ & $\begin{array}{l}\text { This is ROE, representing profitability } \\
\text { of the company }\end{array}$ & $\begin{array}{l}\text { S\&P Capital } \\
\text { IQ }\end{array}$ \\
\hline
\end{tabular}




\begin{tabular}{|c|c|c|c|}
\hline lgta & Log of total assets & Measure the size of the company & $\begin{array}{l}\text { S\&P Capital } \\
\text { IQ }\end{array}$ \\
\hline$m v \_v r$ & Market Capitalization & $\begin{array}{l}\text { This represents the market value of } \\
\text { company }\end{array}$ & $\begin{array}{l}\text { S\&P Capital } \\
\text { IQ }\end{array}$ \\
\hline$b v \_v r$ & Stockholders' Equity & $\begin{array}{l}\text { This represents the book value of the } \\
\text { company }\end{array}$ & $\begin{array}{l}\text { S\&P Capital } \\
\text { IQ }\end{array}$ \\
\hline pvre & Sum of residual earnings & $\begin{array}{l}\text { This measures abnormal earnings of } \\
\text { the company. }\end{array}$ & $\begin{array}{l}\text { Manually } \\
\text { Calculated }\end{array}$ \\
\hline lgaudfee & Log of Audit Fees & This measures the change of audit fees & Annual Report \\
\hline invrecvta & $\begin{array}{l}\text { (Inventory+Receivables)/Total } \\
\text { Assets }\end{array}$ & This measures the audit complexity & $\begin{array}{l}\text { S\&P Capital } \\
\text { IQ }\end{array}$ \\
\hline
\end{tabular}

Table 3 (Correlation Matrix of Model 1)

\begin{tabular}{lrrrrr}
\hline & \multicolumn{1}{c}{ deequi } & \multicolumn{1}{l}{ logsales } & ppeta & cata & mvbv \\
deequi & 1 & & & & \\
logsales & 0.04 & 1 & & & \\
ppeta & -0.0228 & -0.1458 & 1 & & \\
cata & -0.0702 & 0.154 & -0.8006 & 1 & \\
mvbv & 0.631 & 0.0662 & 0.1779 & -0.1884 & 1 \\
\hline
\end{tabular}

Table 4 (Correlation Matrix of Model 3)

\begin{tabular}{lrrrrrr}
\hline & \multicolumn{1}{l}{ lgaudfee } & \multicolumn{1}{c}{ revcost } & audfirm & lgta & nise & deequi \\
lgaudfee & 1 & 1 & & & & \\
revcost & 0.2267 & 1 & & & & \\
audfirm & 0.4707 & -0.0022 & 1 & & & \\
lgta & 0.6838 & -0.0098 & 0.3599 & 1 & & \\
nise & 0.0418 & -0.1768 & 0.1254 & 0.0724 & 1 & \\
deequi & 0.1096 & 0.0354 & 0.1275 & 0.2579 & -0.4639 & 1 \\
\hline
\end{tabular}


Table 5 (Coefficients of Models)

\begin{tabular}{|c|c|c|c|}
\hline & $\begin{array}{c}\text { Model 1 } \\
\text { revcost }\end{array}$ & $\begin{array}{c}\text { Model 2 } \\
\text { mv_vr }\end{array}$ & $\begin{array}{l}\text { Model 3 } \\
\text { lgaudfee }\end{array}$ \\
\hline $\begin{array}{l}\text { main } \\
\text { deequi }\end{array}$ & $\begin{array}{c}0.106^{*} \\
(0.058)\end{array}$ & & $\begin{array}{c}-0.00758 \\
(0.138)\end{array}$ \\
\hline logsales & $\begin{array}{c}0.00516 \\
(0.392)\end{array}$ & & \\
\hline ppeta & $\begin{array}{c}6.929^{* * *} \\
(0.000)\end{array}$ & & \\
\hline cata & $\begin{array}{l}4.443^{* *} \\
(0.014)\end{array}$ & & \\
\hline mvbv & $\begin{array}{c}-0.107^{* *} \\
(0.040)\end{array}$ & & \\
\hline bv_vr & & $\begin{array}{c}2.666^{* * *} \\
(0.000)\end{array}$ & \\
\hline pvre & & $\begin{array}{c}3.341^{* * *} \\
(0.000)\end{array}$ & \\
\hline revcost & & $\begin{array}{l}1804.9 \\
(0.784)\end{array}$ & $\begin{array}{c}0.202^{* * *} \\
(0.001)\end{array}$ \\
\hline audfirm & & & $\begin{array}{c}0.259^{* * *} \\
(0.000)\end{array}$ \\
\hline lgta & & & $\begin{array}{c}0.404^{* * *} \\
(0.000)\end{array}$ \\
\hline nise & & & $\begin{array}{l}-0.0322 \\
(0.776)\end{array}$ \\
\hline _cons & $\begin{array}{c}-5.082^{* * *} \\
(0.002)\end{array}$ & $\begin{array}{l}1302.6 \\
(0.789)\end{array}$ & $\begin{array}{l}3.814^{* * *} \\
(0.000)\end{array}$ \\
\hline$R-s q$ & & 0.891 & 0.583 \\
\hline$F$ & & 146.9 & 27.45 \\
\hline$N$ & 109 & 58 & 104 \\
\hline
\end{tabular}

p-values in parentheses

${ }^{*} \mathrm{p}<.10,{ }^{* *} \mathrm{p}<.05,{ }^{* * *} \mathrm{p}<.01$ 